ZOOLOGIA 30 (1): 107-114, February, 2013

http://dx.doi.org/10.1590/S1984-46702013000100014

\title{
Redescription of Avicularia taunayi and notes on its habitat and geographical distribution (Araneae: Theraphosidae: Aviculariinae)
}

\author{
Rogério Bertani ${ }^{1,3} \&$ Paulo Cesar Motta ${ }^{2}$
}

${ }^{1}$ Laboratório Especial de Ecologia e Evolução, Instituto Butantan. Avenida Vital Brazil 1500, 05503-900 São Paulo, SP, Brazil.
${ }^{2}$ Departamento de Zoologia, Universidade de Brasília. 70910-900 Brasília, DF, Brazil. E-mail: mottapc@unb.br
${ }^{3}$ Corresponding author. E-mail: rbert@butantan.gov.br; rogerio.bertani@uol.com.br

\begin{abstract}
We redescribe the poorly known tarantula species Avicularia taunayi (Mello-Leitão, 1920) and present information on its geographical distribution and habits. The spermatheca of the female is unusual for the genus: short, broad, with a median slight curvature and lobes on its basal, median and distal portions. The male resembles other Avicularia species but can be distinguished by the presence of a tibial apophysis on leg I in conjunction with legs I and IV having roughly the same length and the presence of pale rings on the distal femora, tibiae and metatarsi. Additionally, males and females have three pairs of light brown spots extending from the dorsum to the lateral region of the abdomen. Avicularia taunayi is found in the Brazilian Cerrado, a savannah-like biome. It is one of the aviculariine species with the southernmost distribution, reaching as far South as the Tropic of Capricorn.
\end{abstract}

KEY WORDS. Ancylochiros; Arachnida; Brazil; Cerrado; Tarantula.

The theraphosid Aviculariinae comprises eight genera with species known from the New World and Western Africa (WeST et al. 2008). Most species are arboreal, though some fossorial species are well known in Ephebopus Simon, 1892 (WeST et al. 2008). The taxonomy of Aviculariinae is poorly understood:only Ephebopus was totally revised (West et al. 2008), and the systematic of Avicularia Lamarck, 1818, in particular, is chaotic. Most species of the latter were described briefly during the $19^{\text {th }}$ century and early $20^{\text {th }}$ century. Only a few of the 49 described species (Platnick 2012) can be identified and information on the geographic distribution and habitats of most species is lacking.

Here we redescribe one remarkable Avicularia species. It was originally described by MELLo-Leitão (1920) as a new genus and species, Ancylochiros taunayi Mello-Leitão, 1920, based on a supposed female specimen, collected in Mariana, state of Minas Gerais, Brazil. In his description, Mello-Leitão (1920) stressed the following characteristics of this new genus: palpal tarsus "very bowed at the base; beyond much depressed, a little hollow, with dorsal series of small spines", "posterior sternal sigilla separated from the margin by nearly the same distance which divides them", and in "having the posterior tarsal scopula divided by a longitudinal band of spiniform bristles". He believed that the new genus would be an intermediate form between the Ischnocoleae (Ischnocolinae) and the Avicularieae (Aviculariinae). Later, he published the description of the genus and species in Portuguese, included it in a key to the Brazilian genera and species of Avicularieae, and considered it to be close to Ephebopus. Both genera were considered intermediates between Aviculariinae and Phoneyuseae (now Eumenophorinae) (Mello-
LeITÃo 1923). In his catalog, RoEWER (1942) included Ancylochiros Mello-Leitão, 1920 in the Ischnocolinae.

RAVEN (1985) examined the type of Ancylochiros taunayi and noted that the specimen is a male in the penultimate instar (hence the modified palpal tarsus) and the scopula of tarsus IV was entire. Therefore, the species could not be distinguished from those in the genus Avicularia, and the synonymy between Ancylochiros and Avicularia was established.

Avicularia taunayi would be just one more of the several species in the genus, but the topotypical locality makes it special. The city of Mariana, the type locality, is located in the state of Minas Gerais, which is out of the Amazonian region (where most Avicularia species are found), as well as relatively far from the Brazilian Northeastern region, where species of other aviculariine genera such as Pachistopelma Pocock, 1901 and Iridopelma Pocock, 1901 occur (pers. obs.). In order to try to elucidate the identity of this species, we consulted most arachnid collections in Brazil. We also carried out some field trips trying to find living specimens, and to obtain information on their habitat. As a result, we discovered additional preserved museum specimens, as well as a wild population in the Brazilian Cerrado (a savannah-like biome). Using this new information, we redescribe A. taunayi and provide details on its habitat and natural history.

\section{MATERIAL AND METHODS}

The general description format follows RAVEN (2005) with some modifications; e.g., we do not describe the hair types and the trichobothrial conformation on the legs in as much detail 
as RAVEN. All measurements are in millimeters and were obtained with a Mitutoyo ${ }^{\circledR}$ digital caliper with an error of 0.005 $\mathrm{mm}$. Leg and palp measurements were taken from the dorsal aspect of the left side (unless appendages were lost or obviously regenerated). A Nikon ${ }^{\circledR}$ SMZ1500 dissecting microscope was used for illustrations (with a camera lucida attachment). Abbreviations: (ALE) anterior lateral eyes, (AME) anterior median eyes, (ITC) inferior tarsal claw, (PLE) posterior lateral eyes, (PME) posterior median eyes, (PMS) posterior median spinnerets, (STC) superior tarsal claws.

Specimens of the following institutions were examined: (DZUB) Universidade de Brasília; (IBSP) Instituto Butantan, São Paulo; (MZSP) Museu de Zoologia da Universidade de São Paulo, São Paulo; (ZUEC) Universidade Estadual de Campinas. Urticating hairs terminology follows Cooke et al. (1972). Geographical coordinates: primary sources are between round brackets, secondary sources (Google Earth ${ }^{\circledR}$ ) between square brackets.

\section{TAXONOMY}

\section{Avicularia taunayi (Mello-Leitão, 1920) Figs 1-23, Table I}

Ancylochiros taunayi Mello-Leitão, 1920: 142; 1923: 319; Roewer, 1942: 225; Bonnet, 1955: 316.

Anchylochyros taunayi: Petrunkevitch, 1928: 83 (unjustified emendation per Bonnet, 1955); Strand, 1929: 12.

Anchylochiros taunayi: Petrunkevitch, 1939: 291 (misspelling of Ancylochiros).

Avicularia taunayi: Raven, 1985: 149; Platnick, 2012.

Diagnosis. The female differs from those of other Avicularia species by the shape of the spermathecae: short, broad, with a slight median curvature and lobes on basal, median and distal portions (Figs 6-9). The male differs from those of other Avicularia species by the presence of a tibial apophysis on leg I (Figs 4 and 5) in conjunction with the legs I and IV being roughly the same length (Table I) and the presence of pale rings on the distal femora, tibiae and metatarsi (Fig. 11). Additionally, male and female differ from all those of other Avicularia species by having three pairs of light brown spots extending from the dorsum to lateral region of abdomen, more visible in females (Figs 10 and 11).

Type material. Holotype: BraziL, Minas Gerais: Mariana [20 $22^{\prime} \mathrm{S}, 43^{\circ} 25^{\prime} \mathrm{W}$ ], 1 immature male, J. P. Fonseca leg. (MZSP 327) (examined).

Redescription. Female (IBSP 199). Carapace 17.9 long, 15.2 wide, chelicerae 8.6 . Legs (femur, patella, tibia, metatarsus, tarsus, total): I: $13.0,8.4,9.9,8.4,5.5,45.2$; II: $12.1,7.8$, 9.1, 8.3, 4.0, 41.3; III: $11.4,6.8,8.3,7.5,4.6,38.6$; IV: 14.3, 7.8, 11.4, 10.6, 5.3, 49.4. Palp: 8.9, 5.7, 6.2, -, 6.1, 26.9. Midwidths: femora I-IV $=2.9,3.2,3.2,3.4$, palp $=2.3$; patellae I-IV $=3.4$, $3.3,3.2,3.2$, palp $=2.7$; tibiae $\mathrm{I}-\mathrm{IV}=2.8,2.7,2.8,2.7$, palp $=$ 2.7; metatarsi $\mathrm{I}-\mathrm{IV}=2.2,2.3,2.2,2.1$; tarsi $\mathrm{I}-\mathrm{IV}=2.6,2.4,2.5$,
2.8, palp = 2.5. Abdomen 19.7 long, 11.0 wide. Spinnerets: PMS, 2.3 long, 1.1 wide, 0.1 apart; PLS, 3.6 basal, 1.3 middle, 3.2 distal; midwidths $1.8,1.7,1.4$, respectively. Carapace: length to width 1.18; cephalic area moderately raised, thoracic striae shallow. Fovea: deep, straight, 2.6 wide. Carapace hirsute, covered with long, curly, dense setae and some long stiff scattered setae mainly on cephalic region. Eyes and eye tubercle: eye tubercle 1.0 high, length 2.2, width 3.0. Clypeus 0.4 wide. Anterior eye row procurved, posterior slightly recurved. Eye sizes and inter-distances: AME 0.6, ALE 0.8, PME 0.4, PLE 0.6, AME-AME 0.7, AME-ALE 0.4, AME-PME 0.3, ALE-ALE 1.9, ALEPME 0.4, PME-PME 1.7, PME-PLE 0.1, PLE-PLE 2.4, ALE-PLE 0.3, AME-PLE 0.6. Ratio of eye group width to length 1.9. Maxillae: length to width: 1.73 . Cuspules: $180-200$ spread over ventral inner heel. Maxillary lyra absent. Labium: length 2.5 , width 3.2 , with about 125 cuspules spaced by one diameter from each other on anterior third center. Labio-sternal groove shallow, flat, without visible sigilla. Chelicerae: rastellum absent, basal segments with 10 teeth decreasing in size from distal area and row of small teeth on promargin. Sternum: length 8.7, width 6.0. Posterior angle sharp, separating coxae IV. Sigilla: three pairs, posterior ellipsoidal, inclined at $45^{\circ}$ angle, 1.5 diameter from margin; middle fusiform, less than one diameter from margin; anterior not evident. Legs: legs formula: IV = I II III. Clavate trichobothria: on distal 2/3 of tarsi I-IV. Leg coxae: with sparse soft setae; stridulatory or modified setae lacking. Scopula: tarsi I-IV fully scopulate. Metatarsi I-II, 4/5 scopulate; III, 1/2, IV 1/3 distal scopulate. IV, divided by three wide row of setae. Scopula hairs longest at lateral areas of tarsi and metatarsi, giving spatulate aspect to articles. Spines: absent on all legs and palp. Claws: ITC absent; STC without teeth. Urticating hairs: type II on dorsum of abdomen. Genitalia: Two weakly sclerotized spermathecae with curvature in their middle and lobes from median to distal portions (Figs 6-9).

Color pattern (Figs 10 and 13): Carapace dark brown with light brown hairs. Coxae, labium, sternum and maxilla dark brown. Legs dark brown with light brown, long setae. Distal femora, patellae, tibiae and metatarsi with broad white rings. Abdomen black with three pairs of light brown spots extending from dorsum to lateral region (Fig. 13). Abdomen ventrally black.

Description. Male (DZUB 1675). Carapace 12.1 long, 11.8 wide, chelicerae 4.8. Legs (femur, patella, tibia, metatarsus, tarsus, total): I: $12.0,6.4,8.9,8.9,5.5,41.7$; II: $11.3,5.9,8.8,8.2$, 5.5, 39.7; III: 9.8, 4.9, 7.5, 7.6, 4.8, 34.6; IV: 12.5, 5.6, 10.1, 10.2, 5.0, 43.4. Palp: 7.1, 4.7, 5.6, -, 2.6, 20.0. Midwidths: femora $\mathrm{I}-\mathrm{IV}=2.6,2.6,2.7,2.7$, palp = 1.6; patellae I-IV = 2.6, 2.6, 2.4, 2.5 , palp $=2.0$; tibiae I-IV $=2.2,2.0,1.9,1.9$, palp $=1.8$; metatarsi I-IV = 1.3, 1.4, 1.2, 1.3; tarsi I-IV = 1.5, 1.6, 1.5, 1.4, palp = 1.5. Abdomen 11.1 long, 6.6 wide. Spinnerets: PMS, 1.6 long, 0.5 wide, 0.1 apart; PLS, 1.6 basal, 1.1 middle, 2.2 distal; midwidths 1.2, 1.0, 0.7, respectively.

As in female, except: Carapace: length to width 1.02; thoracic striae inconspicuous. Fovea: 2.7 wide. Carapace hir- 


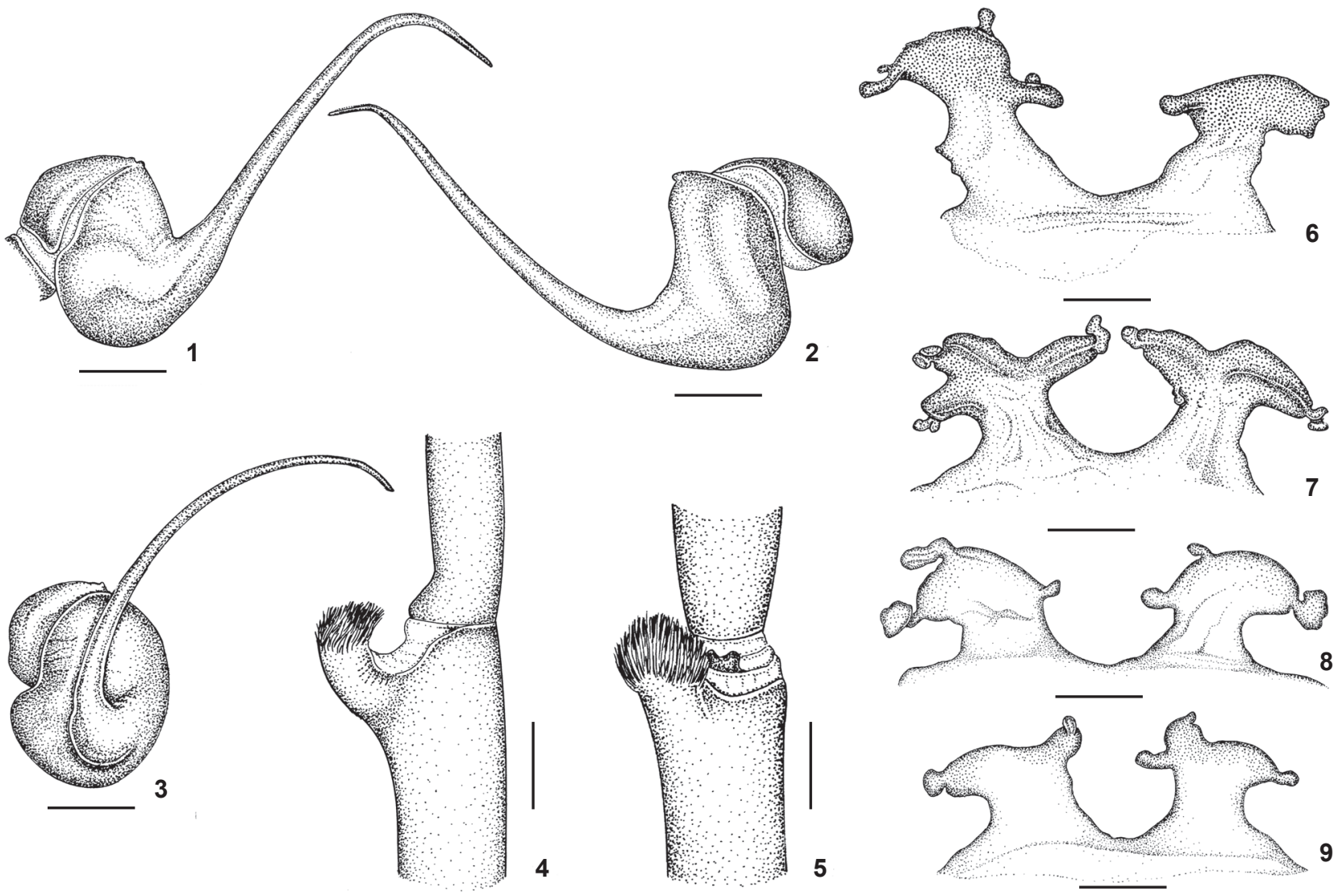

Figures 1-9. Avicularia taunayi: (1-5) male, DZUB 4542: (1-3) left palpal bulb: (1) prolateral; (2) retrolateral; (3) frontal; (4-5) left leg I tibial apophysis: (4) retrolateral; (5) ventral; (6-9) spermathecae: (6) IBSP 199, Barão de Cocais, Minas Gerais; (7) IBSP 4906, Goiás; (8) IBSP 123298, UHE Serra da Mesa, Goiás; (9) DZUB 1979, Brasília, Distrito Federal. Scale bar = $1 \mathrm{~mm}$.

sute, covered with long, curly, dense setae and several long stiff scattered setae from eye tubercle to fovea. Eyes: eye tubercle 0.7 high, length 1.6 , width 2.3. Clypeus 0.4 wide. Posterior eye row straight. Sizes and inter-distances: AME 0.62, ALE 0.54, PME 0.37, PLE 0.48, AME-AME 0.45, AME-ALE 0.20, AMEPME 0.12, ALE-ALE 1.42, ALE-PME 0.56, PME-PME 1.14, PMEPLE 0.10, PLE-PLE 1.74, ALE-PLE 0.20, AME-PLE 0.31. Ratio of eye group width to length 1.75. Maxillae: length to width: 1.78 . Cuspules: 100-150 spread over ventral inner heel. Labium: length 1.5 , width 2.0 , with about 80 cuspules. Chelicerae: basal segments with nine teeth decreasing in size from distal area. Sternum: length 6.1 , width 4.8. Sigilla: three pairs, posterior ellipsoidal, inclined in $45^{\circ}$ angle, middle fusiform, both one diameter from margin; anterior not evident. Legs: Scopula on tarsus IV with few sparse setae. Metatarsus IV, 1/2 distal scopulate. Genitalia: Male palpal embolus 4.8 in length, with slight curvature to retrolateral side (Figs 1-3). Embolus basal, middle and distal width $0.6,0.2$ and 0.04 , respectively. Tegulum 1.2 in length. Tibial apophysis: single, 1.7 long, 1.5 wide, with numerous spiniform setae on tip (Figs 4 and 5). Male metatar- sus I slightly curved, passes by retrolateral side of tibial apophysis without touching it. Cymbium: two subequal lobes, prolateral one triangular in shape, with spiniform process 0.5 long and 0.5 wide on apex.

Color pattern (Fig. 11): As in female, but light brown spots on dorsum of abdomen ill-defined.

Variation. Length of carapace and legs I and IV in Table I. A high degree of morphological variation was detected in the number and development of the spermathecal lobes (Figs 6-9). One basic pattern seems to be the presence of a basal, a median and a distal lobe (Fig. 8). In some specimens, one or more of these lobes may be absent (Fig. 9, left spermatheca) or duplicated (Fig. 6, left spermatheca). Some of these lobes can be so developed that the spermathecae appear branched (Figs 7 and 9).

Ontogeny of the color pattern. Juveniles (Fig. 12) exhibit a similar pattern to other Avicularia species: a dorsal central longitudinal black stripe with four transversal black stripes on each side of the abdomen. The remaining parts of the dorsal and lateral abdomen are reddish. In adult females, the lateral 

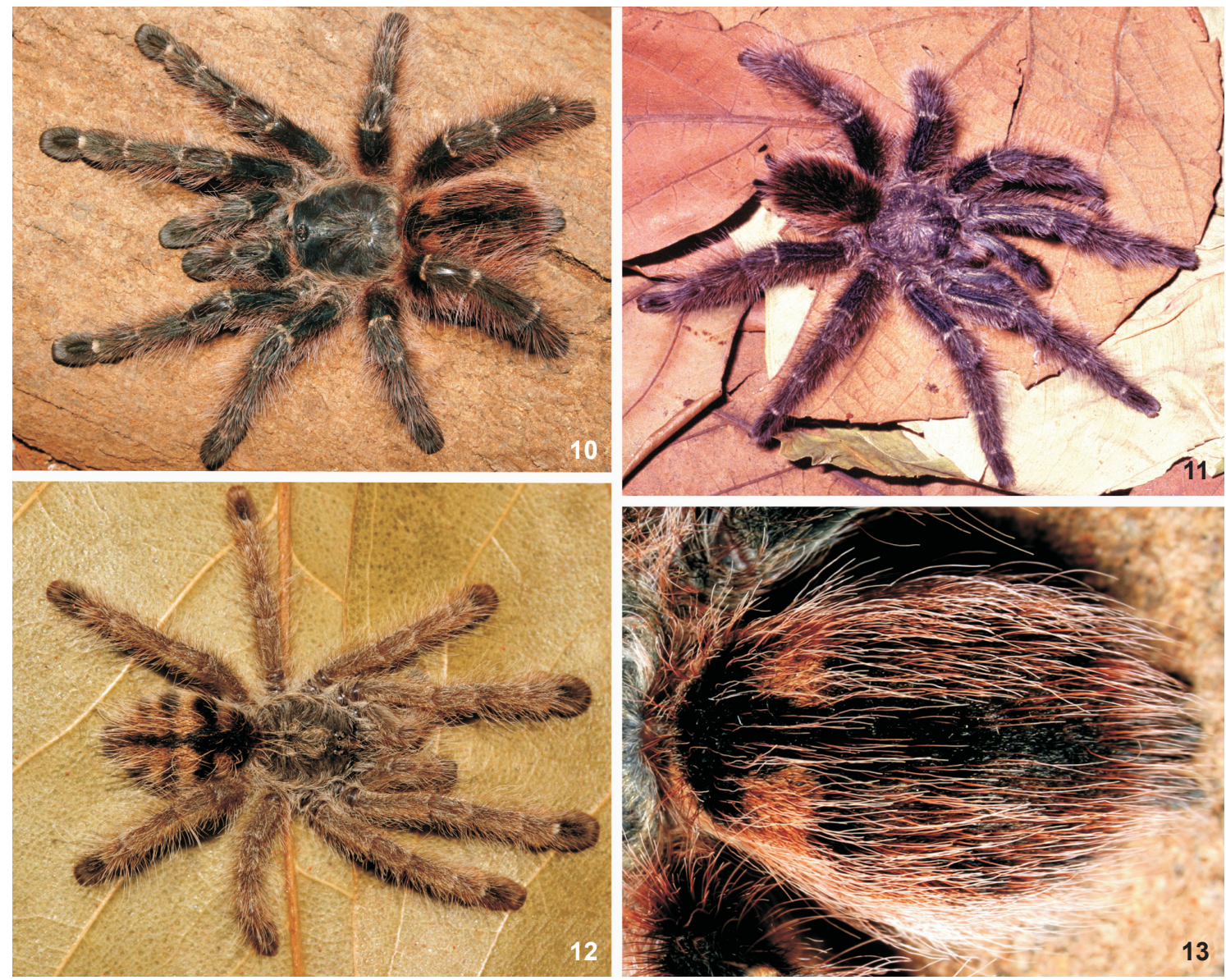

Figures 10-13. Avicularia taunayi: (10) female, from Distrito Federal; (11) male, from Ipamerí, Goiás; (12) juvenile, from Distrito Federal; (13) detail of abdomen dorsum, female, from Distrito Federal. Photos: R. Bertani.

black stripes become larger. However, contrary to what happens in most Avicularia species, the reddish areas do not disappear totally. Consequently, that part of the pattern still remains (Fig. 13).

Distribution. BRAZIL: from the south region of the state of Tocantins southwards to the state of São Paulo, and from the state of Mato Grosso eastwards to the extreme west of the state of Bahia, in the Cerrado biome (see the discussion on natural history below) (Fig. 14). Together with Avicularia sooretama Bertani \& Fukushima, 2009, A. taunayi reaches the southernmost areas among congeners, near the Tropic of Capricorn (records from Duartina $\left[22^{\circ} 24^{\prime} \mathrm{S}, 49^{\circ} 24^{\prime} \mathrm{W}\right]$ and Bebedouro $\left[20^{\circ} 56^{\prime} \mathrm{S}, 48^{\circ} 29^{\prime} \mathrm{W}\right]$ in the state of São Paulo). The absence of records of A. taunayi after 1955, allied to the high degree of deforestation and human impact in this region suggest that the species is locally extinct or close to extinction in the state of São Paulo. Specific sampling efforts in the Cerrado remnants of the region are necessary to ascertain this.

Natural history. A population of $A$. taunayi was discov- ered and some individuals were observed and collected by us in the Distrito Federal, Brazil $\left(15^{\circ} 43^{\prime} 8.84^{\prime \prime} \mathrm{S}, 47^{\circ} 44^{\prime} 6.34^{\prime \prime} \mathrm{W}\right)$ in July 2007 . The area is a slope situated at $1050-1100 \mathrm{~m}$ above sea level. There are residences and small farms in the upper plateau and in lower areas forming mosaics of altered areas with less impacted patches of Cerrado "stricto sensu" vegetation. Since most Avicularia species are known to occur in the rainforest, the presence of this species in a savannah-like biome is unusual. The specific area where the specimens of $A$. taunayi were found is a slope covered with rocky vegetation ("cerrado rupestre") (Fig. 15).

Specimens of A.taunayi were found on small trees in the hill. Of the five specimens found in Brasília (one juvenile and four females), four were on Myrcia tomentosa (Aubl.) DC., 1828 (Myrtaceae) (Figs 15-23) and one on "Jatobá" (Hymenaea sp., Fabaceae) trees. These trees, mainly the former, normally have hollows in the trunk that are used as retreats by the spiders. These hollows can extend for several centimeters down or up and follow the trunk's branching. The aperture to the outside 


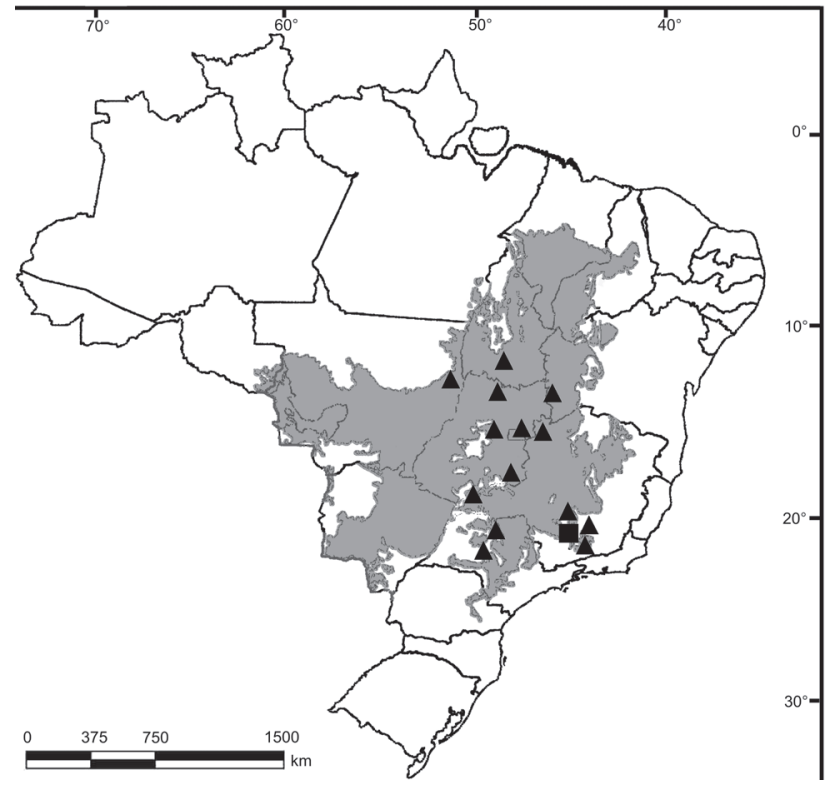

Figure 14. Records of Avicularia taunayi in Brazil. Square = type locality of $A$. taunayi. Triangle $=$ new records. The gray area represents the approximate original distribution of Brazilian Cerrado.

is small (Figs 17-20) when compared to the size of the specimen inhabiting it, and can be hidden by a silky retreat similar to that built by other Avicularia species (Figs 16 and 21-23). The openings positions were 0.5 meter ( 2 specimens), 1 meter ( 2 specimens) and $1.65 \mathrm{~m}$ (1 specimen) in height from the soil. In the locality of Cocalzinho de Goiás, three individuals were found in hollows of M. tomentosa and one in Aspidosperma macrocarpon Mart., 1824 (Apocynaceae) in the "cerrado rupestre" phytophysiognomie (PCM, pers. obs.).

The males $(n=7)$ were collected from February to July, indicating that mating occurs in the end of the rainy season to early in the dry season. In the field, two females were found with egg sacs in July (DZUB 4707). One female (DZUB 2957), which was collected in Brasília (Distrito Federal) on April 14, 2004 and housed in the laboratory, built a completely closed silken retreat from July 9 to 12 and laid eggs on July 14 . The spiderlings $(n=29)$ hatched 80 days later (October 1$)$. About 18 days later (early rainy season), the female opened the shelter and the spiderlings began to disperse.

Additional material examined: BraziL, Tocantins: Peixe (Aproveitamento Hidrelétrico Peixe/Angical, $12^{\circ} 18^{\prime} \mathrm{S}, 48^{\circ} 15^{\prime} \mathrm{W}$ ), 1 immature male, 15 March 2006, R. Bertani leg. (IBSP 123303); Bahia: Jaborandi [ $\left.13^{\circ} 55^{\prime} \mathrm{S}, 46^{\circ} 00^{\prime} \mathrm{W}\right], 1$ male, 27 July 2008, A.F. Mendonça leg. (DZUB 5101); Goiás: Minaçu [Usina Hidrelétrica Serra da Mesa, $\left.13^{\circ} 49^{\prime} \mathrm{S}, 48^{\circ} 18^{\prime} \mathrm{W}\right], 5$ females, 1 immature male, 1997, Equipe de Resgate de Fauna leg. (IBSP 123297-123302); Ipameri [ $\left[17^{\circ} 42^{\prime} \mathrm{S}, 48^{\circ} 10^{\prime} \mathrm{W}\right], 1$ female, 17 March $1952,11^{\circ}$ do $3^{\circ}$ R.I. leg. (IBSP 2847); 1 male, 1 female, February 1996, F.R. Alves
Table I. Lengths, median and standard deviation (SD) of carapace and legs I and IV (femora to tarsi) of Avicularia taunayi.

\begin{tabular}{|c|c|c|c|c|c|}
\hline \multirow{2}{*}{ Sex } & \multirow{2}{*}{ Number } & \multicolumn{4}{|c|}{ Length } \\
\hline & & Carapace & Leg I & Leg IV & Leg IV/Leg I \\
\hline \multirow[t]{7}{*}{ Male } & DZUB2025 & 14.5 & 47.3 & 49.2 & 1.040 \\
\hline & DZUB4315 & 12.3 & 39.0 & 41.5 & 1.064 \\
\hline & DZUB4542 & 15.9 & 49.5 & 52.1 & 1.052 \\
\hline & DZUB1675 & 12.0 & 41.0 & 43.0 & 1.048 \\
\hline & IBSP14397 & 14.7 & 48.9 & 51.9 & 1.061 \\
\hline & & & & Median & 1.053 \\
\hline & & & & SD & 0.009 \\
\hline \multirow[t]{22}{*}{ Female } & DZUB4707 & 6.2 & 18.0 & 18.4 & 1.022 \\
\hline & IBSP3384 & 11.2 & 28.9 & 31.1 & 1.076 \\
\hline & DZUB3981 & 13.1 & 35.5 & 37.6 & 1.059 \\
\hline & IBSP3400 & 13.7 & 35.4 & 39.5 & 1.115 \\
\hline & DZUB3980 & 14.7 & 38.7 & 41.7 & 1.077 \\
\hline & IBSP 123297 & 14.9 & 39.8 & 43.1 & 1.082 \\
\hline & DZUB352 & 15.7 & 39.5 & 42.2 & 1.068 \\
\hline & IBSP 123298 & 16.0 & 41.7 & 45.0 & 1.079 \\
\hline & IBSP123299 & 16.1 & 42.2 & 45.2 & 1.071 \\
\hline & DZUB4707 & 17.6 & 46.5 & 49.5 & 1.064 \\
\hline & IBSP4032 & 17.8 & 43.7 & 46.6 & 1.066 \\
\hline & IBSP199 & 17.9 & 45.2 & 49.4 & 1.092 \\
\hline & IBSP123300 & 18.4 & 48.2 & 52.3 & 1.085 \\
\hline & IBSP1365 & 18.7 & 45.4 & 47.7 & 1.050 \\
\hline & DZUB1979 & 18.9 & 47.9 & 50.8 & 1.060 \\
\hline & DZUB2603 & 19.1 & 46.2 & 49.2 & 1.064 \\
\hline & IBSP4906 & 19.2 & 48.3 & 51.3 & 1.062 \\
\hline & IBSP2847 & 19.7 & 47.6 & 50.4 & 1.058 \\
\hline & IBSP14397 & 13.4 & 38.1 & 41.5 & 1.089 \\
\hline & ZUEC018 & 16.5 & 41.4 & 43.4 & 1.048 \\
\hline & & & & Median & 1.069 \\
\hline & & & & SD & 0.019 \\
\hline \multirow[t]{3}{*}{ Immature male } & IBSP123302 & 12.7 & 37.0 & 40.1 & 1.083 \\
\hline & IBSP3471 & 10.2 & 28.5 & 29.4 & 1.031 \\
\hline & IBSP123303 & 7.4 & 21.5 & 22.2 & 1.032 \\
\hline \multirow[t]{3}{*}{ Holotype } & MZSP327 & 11.8 & 34.9 & 36.9 & 1.057 \\
\hline & & & & Median & 1.051 \\
\hline & & & & SD & 0.024 \\
\hline
\end{tabular}

leg. (IBSP 14397); Goiás (120 km from Brasília), 1 female, 7 November 1986, L.L. Baumgratz leg. (IBSP 4906); Cocalzinho de

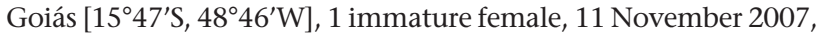
P.C. Motta leg. (DZUB 5027); Distrito Federal: Brasília [Lago Sul, $\left.15^{\circ} 50^{\prime} \mathrm{S}, 47^{\circ} 49^{\prime} \mathrm{W}\right], 1$ male, 14 May 2002, R.A. Brandão and G. Zerbini leg. (DZUB 1675); 1 female, 15 November 2002, F. Brasil leg. (DZUB 1979); (Paranoá, 15²4'8.84"S, 47²4'6.34"W), 1 male, 

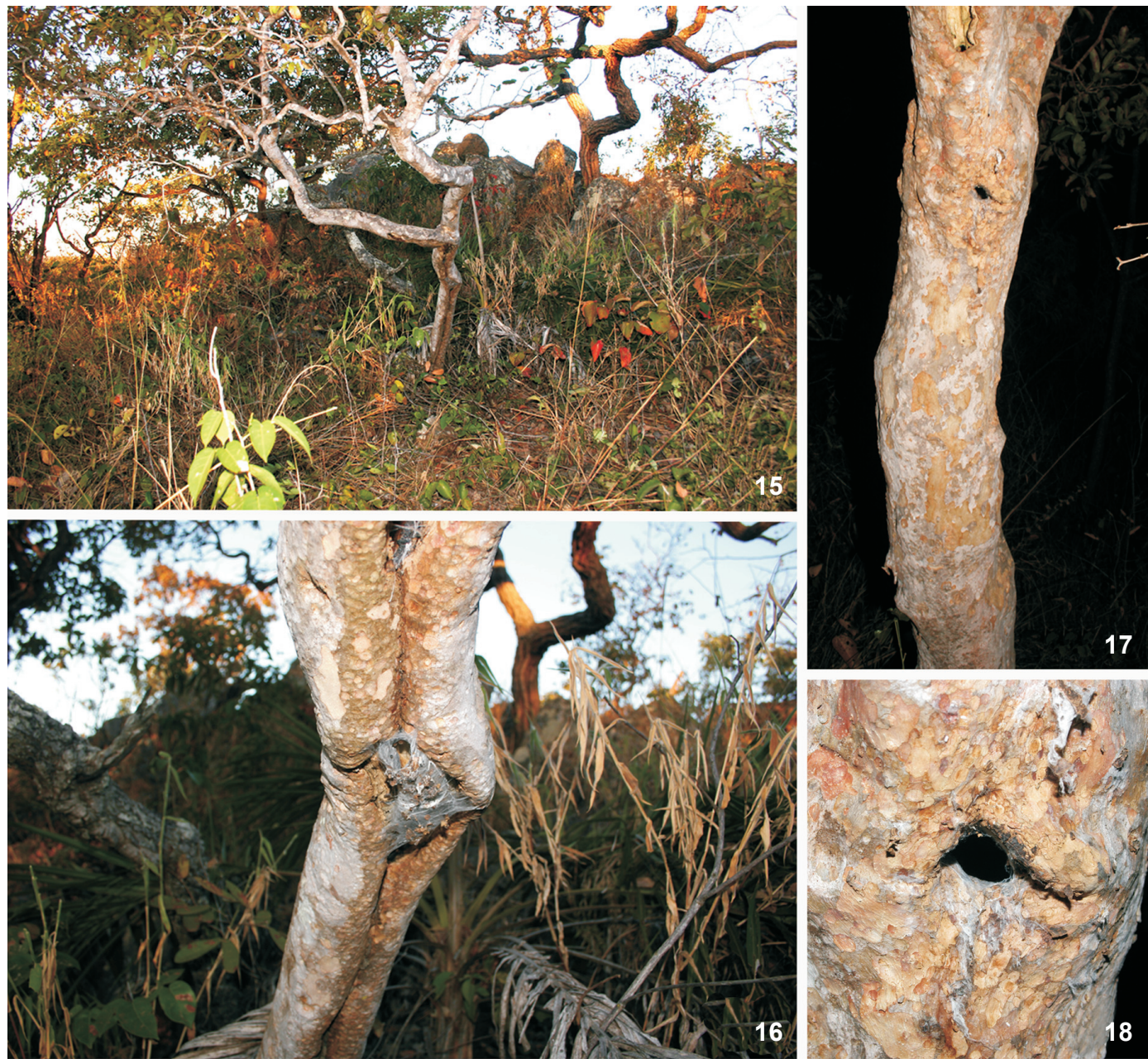

17
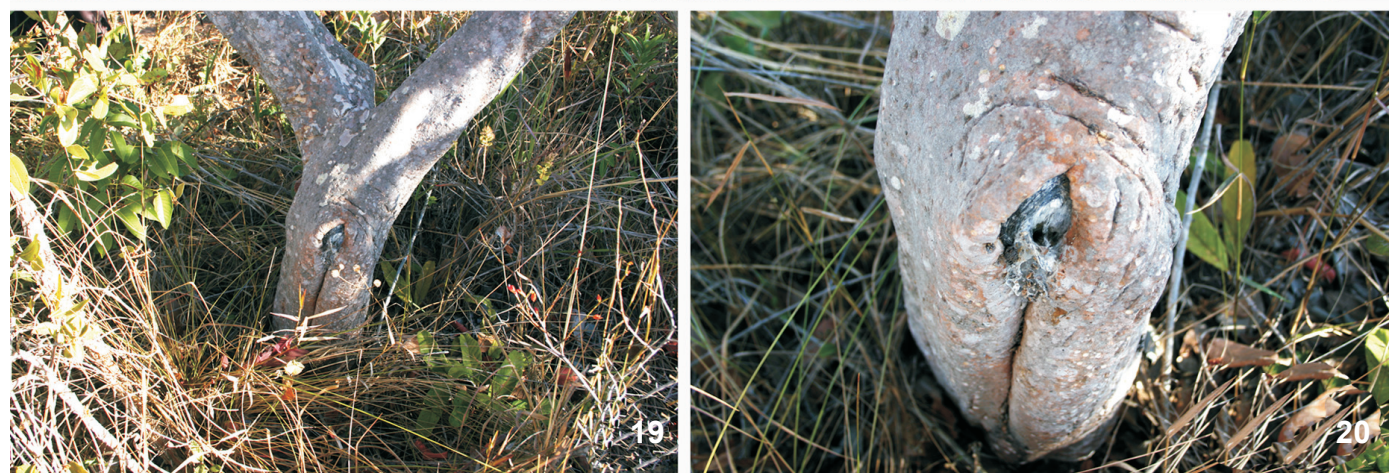

Figures 15-20. Avicularia taunayi habitat in Distrito Federal, Brazil: (15) general view of the area with a Myrcia tomentosa tree in the center; (16) same, detail of the spider retreat; (17) aperture leading to the spider shelter in Myrcia tomentosa; (18) same, detail; (19-20) retreat aperture positioned close to the ground. Photos: R. Bertani.

03 March 2007, P. Jotta leg. (DZUB 4542); 1 female, 1 immature female, 12 July 2007, R. Bertani, C.S. Fukushima, R.H. Nagahama, P.C. Motta, P. Jotta leg. (DZUB 4707); Sobradinho [Colorado,
Córrego do Urubu, $\left.15^{\circ} 42^{\prime} \mathrm{S}, 47^{\circ} 51^{\prime} \mathrm{W}\right]$ ], 1 female, 1 January 1999 , J. Marinho-Filho leg. (DZUB 352), 1 male, 26 February 2004, J. Marinho-Filho leg. (DZUB 2025), 1 male, 2 July 2006, I. Wagas 

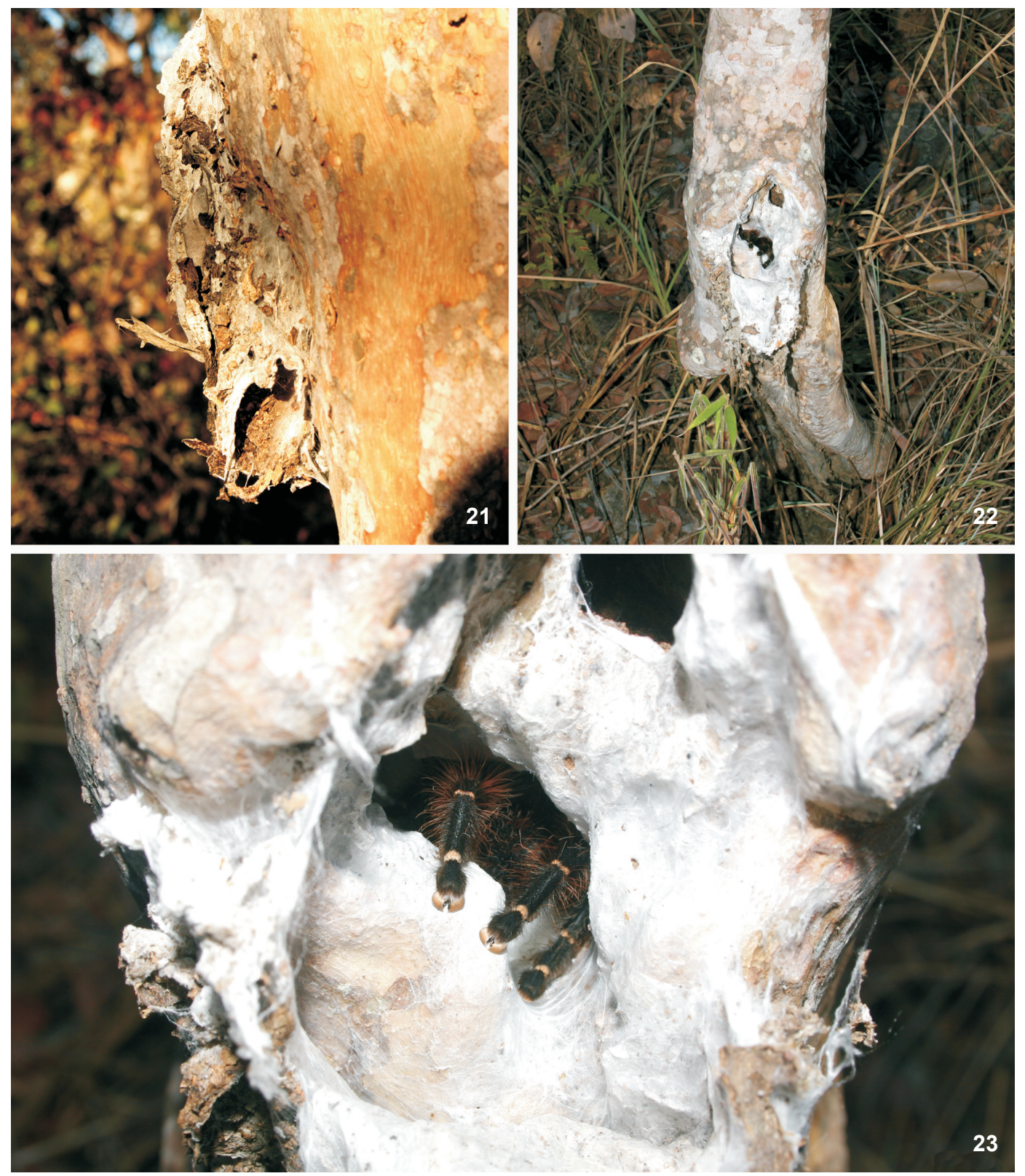

\section{.}




\section{DISCUSSION}

Mello-Leitão (1920) described the new genus and species Ancylochiros taunayi characterizing it mainly by the unusual shape of the palpal tarsi. As already stated by RAVEN (1985), this was an indication that the male is immature, not a species apomorphy. Despite the fact that the type is immature, it is possible to determine the species identity when the information obtained from examination of the holotype is considered in conjunction with the original description and the type locality data. The holotype has legs I and IV almost of the same length (Table I; leg IV is only 0.057 longer than I); the description makes reference to a black abdomen, with the dorsum having three pairs of large, oblique, rusty spots; and the type locality is in Mariana, state of Minas Gerais, is out of the geographic distribution of other Avicularia species. The specimens examined in this work and proceeding from localities neighboring the type locality (specially a female from Barão de Cocais, Minas Gerais, roughly $50 \mathrm{~km}$ from type locality) have the above characteristics and match the species description.

Avicularia taunayi has a modified spermatheca, broad and with several lobes, distinct from that of other Avicularia species. However, we do not think this character alone is enough to revalidate Ancylochiros. This question will be resolved only when the morphological variability and relationships of most Avicularia species are better understood. For now, we prefer to consider the character to be a putative autapomorphy for the species

\section{ACKNOWLEDGMENTS}

We thank Paula Jotta and her family for the help and kind support when we were collecting specimens in Distrito Federal. Roberto Nagahama and Caroline Sayuri Fukushima are thanked for their aid with field work. IBAMA is thanked for collection permits. We are grateful to Ricardo Pinto da Rocha, Andre V.L. Freitas and Artur N. Furegatti for specimen loans, and Caroline Fukushima for her critical review of the manuscript. Thanks to Kátia M. Faria who kindly made the illustra- tions and José do Carmo M. Lima for plant identification. We also thank Robert Raven for valued comments on a previous version of the manuscript. Abel Pérez Gonzáles and two other anonymous reviewers are thanked for improving the manuscript. Support for RB: FAPESP 03/12587-4.

\section{LITERATURE CITED}

BONNET, P. 1955. Bibliographia araneorum. Toulouse, 2(1): 1-918.

CоOKE, J.A.L.; V.D. Rотн \& F.H. Miller. 1972. The urticating hairs of theraphosid spiders. American Museum Novitates 2498: $1-43$.

Mello-Leitão, C.F. 1920. An interesting new genus of Aviculariidae. Annals and Magazine of Natural History 6: 141-143.

Mello-Leitão, C.F. 1923. Theraphosoideas do Brasil. Revista do Museu Paulista 13: 1-438.

Petrunkevitch, A. 1928. Systema Aranearum. Transactions of the Connecticut Academy of Arts and Science 29: 1-270.

Petrunkevitch, A. 1939. Catalogue of American spiders. Part one. Transactions of the Connecticut Academy of Arts and Science 33: 133-338.

Platnick, N.I. 2012. The world spider catalog version 12.5. American Museum of Natural History. Available online at: http://research.amnh.org/iz/spiders/catalog. DOI:10.5531/ db.iz.0001. [Accessed 07.VI.2012].

Raven, R.J. 1985. The spider infraorder Mygalomorphae (Araneae): Cladistics and systematics. Bulletin of the American Museum of Natural History 182: 1-180.

RAVEN, R.J. 2005. A new tarantula species from northern Australia (Araneae, Theraphosidae). Zootaxa 1004: 15-28.

Roewer, C.F. 1942. Katalog der Araneae von 1758 bis 1940. Bremen, 1, 1040p.

STRAND, E. 1929. Zoological and palaeontological nomenclatorial notes. Acta Universitatis Latviensis 20: 1-29.

West, R.C.; S.D. Marshall; C.S. Fukushima \& R. Bertani. 2008. Review and cladistic analysis of the Neotropical tarantula genus Ephebopus Simon 1892 (Araneae: Theraphosidae) with notes on the Aviculariinae. Zootaxa 1849: 35-58.

Submitted: 07.VI.2012; Accepted: 26.VIII.2012.

Editorial responsibility: Gabriel L.F. Mejdalani 